IMP Journal

Strategic practices of subsidiary positioning in business networks

Sari Laari-Salmela, Tuija Mainela, Elina Pernu, Vesa Puhakka,

To cite this document: Sari Laari-Salmela, Tuija Mainela, Elina Pernu, Vesa Puhakka, "Strategic practices of subsidiary positioning in business networks", IMP Journal, https://doi.org/10.1108/IMP-03-2017-0008

\title{
Strategic Practices of Subsidiary Positioning in Business Networks
}

\begin{abstract}
Purpose: The present study examines subsidiary positioning within the dynamic business networks in the context of multinational companies (MNCs). The research question of the study is: How does the positioning of a subsidiary emerge through strategic practices in the dynamic business networks of an MNC?
\end{abstract}

Design/methodology/approach: The study relies on the IMP view on strategy with focus on market positioning activity, and the strategy-as-practice approach. Positioning is seen as a question of strategic practices in the interactive spheres of the subsidiaries. In the empirical part of the study, we examine the practices of a forest machine industry multinational through longitudinal interview and archival data on three of its sales subsidiaries in Sweden, Russia, and the USA.

Originality/value: Prior research has focused either on the internal organizing of the MNCs or embeddedness of subsidiaries into their local environment. Less attention has been paid to the practices through which the subsidiaries deal with the inevitable tensions at the intersection of the internal and external networks.

Findings: The study defines core tensions at subsidiary interactive spheres and the related strategic practices that shape the positioning of the subsidiaries. The study models the practicebased network positioning of MNC subsidiaries as a dynamic play of tensions.

Keywords: positioning, strategic practices, subsidiary, business network, MNC

Article classification: Research paper 


\section{Strategic Practices of Subsidiary Positioning in Business Networks}

\section{Introduction}

Multinational companies (MNCs) build their growth on global operations. By definition, an MNC consists of the headquarters and the subsidiaries operating in the cross-border business networks (Hedlund, 1986). Despite being part of the same organization, the strategic practices of two subsidiaries are often very different from each other (Birkinshaw \& Hood, 1998; Ljung \& Pahlberg, 2015). The differences have been seen connected both to the organizational design choices (Bartlett \& Ghoshal, 1989; Pedersen et al., 2014) and to the characteristics of the local market networks (Andersson et al., 2002; Ljung \& Pahlberg, 2015). The interactions within the MNC internal networks condition the strategic practice of the subsidiary as much as the interactions in the local market networks. This makes network positioning one of the core realms of strategic decision making in the MNC context.

Still, strategy researchers have paid rather limited attention to the networks of firms and network researchers have tended to put less attention to the questions of strategy (Baraldi et al., 2007). In network research, the limited attention can be seen related to the debate on the possibilities of strategic management in network context (see e.g. Easton, 1992; Håkansson \& Snehota, 1989; Möller \& Svahn, 2003; Ritter, Wilkinson \& Johnston, 2004). In the end, however, firms as actors in business networks have intentions, interpret the surrounding context, and take strategic action with respect to the positioning of the firm (Johanson \& Mattsson, 1992, p. 205). The ways in which MNC managers construct strategic moves have been noted complex and without sufficient research (Bouquet \& Birkinshaw, 2011).

The present study aims to elaborate on the IMP view of strategy (see Baraldi et al., 2007; Jüttner \& Schlange, 1996) by defining the mechanism of subsidiary positioning at the intersection of MNC internal and external interaction spheres. Prior research on MNCs has 
focused either on the internal organizing of the MNCs or embeddedness of subsidiaries into their local environment. Less attention has been paid to the practices through which the subsidiaries operate at the intersection of the internal and external networks in positioning of the subsidiary. We define network position as the way an organization is connected to other actors through the relationships it has with them (Johansson \& Mattsson, 1988). With positioning we refer to the continuous process through which the network position of an organization evolves due to the relationship dynamics and the organization's actions and reactions that have an effect on these relationships. We examine positioning neither as an issue of headquarters' strategic decision nor as a structural choice. Instead, we examine the strategic practices at the interactive spheres of the subsidiaries that shape their positioning. The primary research question of the study is: How does the positioning of a subsidiary emerge through strategic practices in the changing MNC networks?

We aim to contribute to the IMP view on strategy through elaborating on the process of network positioning in the MNC context as a process of strategic practices. On the basis of the markets-as-networks approach, international market positioning is a relational activity by individuals acting in the business relationships to change the position of the company from outsider to insider (Johanson \& Vahlne, 2009). Through the strategy-as-practice lens, strategy is " a situated, socially accomplished activity constructed through the actions and interactions of multiple actors" (Jarzabkowski, 2005, p. 7). On this basis, the strategic processes of MNCs and their subsidiaries intimately build on their internal and external relationship practices. We, thus, conceptualize strategy as a practice that is embedded in the work of managers both within and outside the boundaries of the MNC (cf. Bouquet \& Birkinshaw, 2011). In the empirical part of the study, we examine a forest machine industry multinational through longitudinal interview and archival data on three of its subsidiaries in Sweden, Russia, and the USA. In search for the mechanism of subsidiary positioning of an $\mathrm{MNC}$ we see the particular tensions 
at the two interactive spheres as the key drivers of the strategic practices. As a result, we model the practice-based network positioning of MNC subsidiaries as a dynamic play of tensions.

In the following, we will first discuss the IMP view on strategy and network positioning of subsidiaries as a key strategic activity of MNCs. We then turn to the strategy-as-practice view to conceptualize the subsidiary strategy-making at the intersection of the internal and external networks. The third section presents the empirical research methods. On the basis of the data analysis we define the core tensions at the interactive spheres and examine the strategic practices that shape the positioning of the subsidiaries. We conclude with implications on the IMP view on strategy and on the MNC research on subsidiary positioning.

\section{Strategy as a Practice of Subsidiary Positioning in Business Networks}

As all markets are networks, on entering a new market a firm faces the strategic challenge of positioning itself among the pre-existing members of the network (Thorelli, 1986; Johanson \& Mattsson, 1988). Therefore, the actions of firms have been suggested well explained in terms of their positions that both facilitate and constrain their actions (Powell \& Smith-Doerr, 1994, p. 369). Furthermore, networks are constantly shaped by the actions and interactions with other actors to influence and change the network positions (Håkansson \& Snehota, 1989). Strategymaking in a network context is thus interactive by its nature and the strategy itself an emerging pattern of activities both with and without managerial intention in its creation (Baraldi et al., 2007; Jüttner \& Schlange, 1996; Cheng and Holmen, 2015).

\subsection{Strategy as network positioning}

As we study strategy of an MNC through its subsidiaries we see the concept of position at the core of strategy-making (see Easton \& Axelsson, 1992; Mattsson, 1987). In our view, in the establishment of subsidiaries, the MNCs create a new business unit that strives to 
establish a favorable position in its markets of operation, on the mandate of the headquarters.

The concept of position has received attention within the markets-as-networks approach early on. According to Johanson and Mattsson (1988) network positions describe how the individual actors in the network are related to each other in the network structure. Network position is the result of investments in exchange relationships and characterizes the actor's current links as well as forms the base for its future strategic actions. Position can be characterized at micro and macro levels (Johanson \& Mattsson, 1988). At the micro level, position is about the type of exchange relationships of an actor and the identities of its counterparts in those relationships, i.e. with which and what kinds of actors the company has exchange relationships. The macro position is about the role of an actor at the network level. The role is dependent on the functions of the actor in the production system and the relative importance of the actor's resources in relation to the resources and activities of the others in the network. The position of a firm is an important part of its network identity as it is the basis for the development possibilities and constraints of the firm (Johanson \& Mattsson, 1987; Schepis, Purchase \& Ellis, 2014).

The IMP view of strategy emphasizes the way in which a firm relates its activities and resources to other actors in the network to influence its network position (Baraldi et al., 2007; Holmen \& Pedersen, 2003; Cheng and Holmen, 2015). At the core of strategy in network context is, therefore, the strategic activity of positioning. Positioning most often refers to the maintenance or change of the relative location of the firm in the network (Easton \& Axelsson, 1992; Cheng \& Havenvid, 2017). However, in business networks strategic action is more often seen as incremental and emergent than causing radical change and being deliberate (Harrison, Holmen \& Pedersen, 2010). In positioning companies operate on the basis of informational inputs that are often ambiguous, uncertain and equivocal and there exist many possible sets of outcomes that might occur. This makes a network position difficult to predict, 
plan or keep stable. Instead it emerges as a result of the daily practices of the managers in relation to other parties.

Positioning is a strategic process in which the external relationships are changed and actions taken to place the firm in a stronger competitive stance in the market (Håkansson \& Snehota, 1989; Melin, 1989). Still, not all the changes are a result of intentional actions for changing the competitive position. Networks include change that is more haphazard or takes place as a result of changes in other organizations. Therefore, strategy in a network context holds two sides: those management activities the objective of which is to cause changes (deliberate), and those that are reactions to the changes in the relationships (emergent) (Håkansson \& Snehota, 1995; cf. Mintzberg et al., 1998). Positioning has been related primarily to the deliberate type of strategy-making in which maintaining or changing the position is a matter of strategic choice (Harrison \& Prenkert, 2009). However, due to the intertwinedness of the actors in networks, the interactions shape both parties on an everyday level. The strategic choices affect the relationships, and the relationships influence the firm's strategic choices (Håkansson \& Ford, 2002; Hulthén \& Torvatn, 2014; Gadde, Huemer \& Håkansson, 2003; Mota, de Castro \& Brito, 2016). Position can be seen both as a continuously changing condition of strategy making in a network context as well as the outcome of this process.

The strategic approach to positioning makes one specifically interested in the proactive processes for network change (Johanson \& Mattsson, 1992; cf. Medlin \& Törnroos, 2014). Critical proactive activity takes place in the inter-organizational interaction spaces bringing together collective and self-interests, and mutual and specific interests of organizations (Medlin \& Törnroos, 2014). In these spaces both resources, activities and interests are collectively formed and companies can try to influence and evaluate the effects of their actions at the network level (Cheng \& Havenvid, 2017; Medlin \& Törnroos, 2014; Munksgaard \& Medlin, 
2014; Szalkai \& Magyar, 2017). On the basis of the above, we bring to the fore positioning as a strategic process that takes place interactively in the inter-organizational interaction spaces within networks.

\subsection{Strategy-as-practice view to subsidiary positioning}

From the network perspective, an MNC is a complex web of interdependent relationships within which individuals are operating (Forsgren, 2008; Henneberg et al., 2010). The strength of MNCs is in their nature as loosely coupled social communities (Piekkari \& Welch, 2010) that develop competitive advantage through accumulation of knowledge and competencies from different parts of the world (Adenfelt \& Lagerström, 2006; Andersson et al., 2002; Gupta \& Govindarajan, 2000). Still, it is a challenge at the corporate level to achieve sufficient knowledge of the networks and actions of the subsidiaries (Vahlne et al., 2012). Subsidiaries are differentiated in their business conditions, coordination processes and in their social and cultural environments (Ghoshal et al., 1994; Forsgren, 2008). Each subsidiary is embedded into its own local network of relationships, which differs from the networks of other subsidiaries (Forsgren, 2008). In these local networks, headquarters is an outsider (Forsgren, 2008; Nell et al., 2011). Yet, subsidiaries are not independent actors.

The interfaces of the internal and external networks of MNCs have been covered primarily as a question of standardization versus local adaptation in the process of internal decision-making (Bartlett \& Ghoshal, 2002). However, the multiple embeddedness of subsidiaries creates a need for balancing the strategic roles of the subsidiaries (Meyer, Mudambi, \& Narula, 2011). In a business network conceptualization of MNC's international operations, the foreign subsidiaries circumscribe an interaction space for connections between internal and external structures and interests, that exist at both organizational and individual 
levels (Pernu et al., 2014). On this basis, MNCs provide an interesting setting for examination of strategy as a network embedded practice.

Along with the IMP view on strategy, we follow the practice approach in strategy (Whittington, 1996; Jarzabkowski, 2004; Jarzabkowski \& Spee, 2009) in which practices are seen as embodied, materially mediated arrays of human activity centrally organized around shared practical understanding (Schatzki, 2001). This means that "from the social practices viewpoint, everyday strategy practices are discernible patterns of actions arising from habituated tendencies and internalized dispositions rather than from deliberate, purposeful goal-setting initiatives" (Chia \& MacKay, 2007, p. 2017).

We wish to gain an embedded view of strategy by revealing the underlying patterns of a firm's activities and the mechanism that produces it (Jarzabkowski, Kaplan, Seidl \& Whittington, 2016). Being about strategic choices, decision-making naturally becomes a part of strategizing activities. However, when adopting a mechanism-based explanation, the decisions are not seen as causal triggers, but events are produced by generative mechanisms as a whole (Chia, 1994). We understand the logic behind the strategic activities as the most core part of the firm's strategy; the immanent logic emerging through practice constitutes strategy (Chia \& MacKay, 2007; MacKay \& Chia, 2013).

Regnér (2003) found out that strategy-making is profoundly different in the 'center' (i.e. in the corporate and divisional management and/or board of directors) than in the 'periphery' (i.e. in the subsidiaries, projects, and/or business and technology units) farther away from the top management. The former relies on deductive approach involving a more planning oriented industry and exploitation focus, whereas the latter's strategy-making is inductive, focusing more on an exploration through trial and error. Chia and Holt (2006) build on Regnér's distinction of strategy-making to present building and dwelling modes of strategy. The dominant building mode is about deliberate strategic aims and plans, but 
it is seen constantly preceded by the dwelling mode as an existential condition (Heidegger, 1971, p. 148) in which strategy emerges non-deliberately through everyday practical coping (Chia \& Holt, 2006). The dominant building mode of strategizing derives from the more basic dwelling mode. The dwelling mode does not require intention and purposeful goal-orientation, but consistency in action is explained via a modus operandi: "an internalized disposition to act in a manner congruent with past actions and experiences" (Chia \& Holt 2006: 635).

Figure 1 summarizes the strategic practice based conceptualization of the subsidiary positioning in business networks. Basic tenet of the IMP view of strategy is the network embeddedness of firms and their activity (Johanson \& Snehota, 1989; Baraldi et al., 2007). The contextual view by the strategy-as-practice approach goes well with the network view of strategy by appreciating the culturally mediated and relational methods of working (Chia \& Holt, 2006). Combining the views, we note, on one hand, resource and activity coordination through more center-lead, deductive, i.e. intentional, purposeful, and goaloriented, deliberate strategy-making. On the other hand, strategizing involves emergent coping conditioned by the network embeddedness at the inductive sphere of strategy-making. In MNCs multiple embeddedness is emphasized as the subsidiaries are embedded in both internal MNC networks and local market networks. This means existence of two overlapping interaction spheres in their strategy-making creating to the managers a need to manage subsidiary positioning at this intersection.

Insert Figure 1 about here. 


\section{Research Methodology}

We adopt a critical realist epistemological orientation (Easton, 2010; Tsoukas, 1989) and see there exist a reality independent of us to be discovered. The reality is, however, not obvious or transparent but the researcher is to define the causal powers in action to determine the examined phenomenon (Tsoukas, 1989). Individuals having experienced the phenomenon are seen to be able to tell about the reality by describing the events and their experiences of them but the revealing of the mechanism requires analytic processes such as retroduction and judgmental rationalism (Ryan et al., 2012).

\subsection{Research strategy}

This study utilizes an empirical case study to generate in-depth knowledge (Creswell, 2013; Silverman, 2005) about the strategic practices of MNC subsidiaries in their network positioning. Case study as a research strategy allows us to gain holistic descriptions of real life events (Halinen \& Törnroos, 2005; Piekkari et al., 2010). We adopt an instrumental case study design with an interest in the specific case as such and without an attempt for statistical generalization (Silverman, 2005). The aim of the case study is to provide deeper insight into the productive dynamics that exist in a single setting (Piekkari et al., 2010). Thus, the focus is broader than just the case itself.

The empirical research is designed as a longitudinal embedded single case study (Halinen \& Törnroos, 2005). The longitudinal data have been collected in two time periods in the same case and subcases (Flick, 2004; Halinen \& Mainela, 2013). The subsidiary positioning practice forms the main unit of analysis. Our case MNC is one of the world's leading manufacturers of forest machines for the cut-to-length method. The case company has been selected based on purposive and theoretical sampling. Thus, the case well illustrates features that are interesting from the research point of view and is theoretically meaningful to allow for elaborating the 
conceptual framework further through in-depth examination (Silverman, 2005). As MNCs are loosely coupled organizations with significant differences between local units the embdedded case strategy was seen important for in-depth understanding of the case. The sales subsidiaries in Sweden, Russia, and the USA were selected under scrutiny because of their strategic importance in the corporation and expected differences in their practices and local networks.

\subsection{Data collection and analysis}

We approach the case by using both archival and interview data to track variation and change in the subsidiaries of the globally operating MNC (Creswell, 2013). The archival data consists of written sources, such as the annual reports, press releases, web pages and brochures of the firm as well as industry analyses (see Table 1). Understanding of the industry context and the operations and structure of the case company was first built through review of the written material. The written material was collected from year 2000 until year 2015 .

The interviewing involved two rounds. The interviews started with the Chairman of the Board and the CEO of the firm in February 2014 and continued with an interview with the Chairman of the Board and the Managing Directors of the three subsidiaries in April 2014. The first round interviews concentrated on the history of the firm, internationalization, internal organizing of the MNC and the development of each of the subsidiaries. The CEO also organized a factory visit and described the production process and ideology of the company as well as his history in the firm. Organizational culture, atmosphere, and management practices could be observed both during the factory visit and during the yearly subsidiary meeting in 2014 and in the informal discussions during these events. Information about the corporate and subsidiary operations and culture was also received through video data by the firm and its subsidiaries. These data were analyzed together with the archival data and resulted in the 
description of the MNC's internationalization and organizational culture as well as the development of the three subsidiaries in their markets of operation.

The second round of interviewing took place in spring 2016 and included the interviews of the same people as on the first round. The second round had two purposes. One was to validate the interpretations made on the basis of the analysis of the first round data. The other was to collect longitudinal data on the development of the three subsidiaries. All interviews, therefore, had two parallel themes so that we discussed the first round findings and asked further detail on them and then covered the developments in the subsidiaries over the last two years. All the interviews were tape-recorded and verbatim transcribed. The ten interviews were on average 1 hour 13 minutes long and produced together 733 minutes of recordings. The first round interviews were made face-to-face. The second round interviews of the three subsidiary managing directors were conducted over a video conference. They all worked technically well and were relaxed in their atmosphere as the personal relationships between the researchers and the informants had been established on the first round.

Insert Table 1 about here.

The empirical data was analyzed through content analytical procedure (see Denzin \& Lincoln 2000; Ghauri 2004). First, the archival data was analyzed to produce a storyline of the MNC's development and its international operations. Second, the interview transcripts and the other data were analyzed with a practice lens to create an understanding of the practices and the ways of operating in the subsidiaries. The practices were then compared at the level of subsidiaries by focusing on the similarieties and differences. Finally, the conceptual modeling of the phenomenon was elaborated through reconstruction of the practices of the three 
subsidiaries in their interactive spheres, as the practice-based network positioning of the MNCs. In search for the mechanism of the network strategy of an MNC we came to see the particular tensions as the key drivers of the developments.

\section{Practice-based Network Positioning in Forest Machine Industry}

The MNC has operated in the forest machine industry since its establishment in 1970. The company started up with the aim of making a forest machine that would be more durable than the machines in the market at the time. As of now, the company designs, produces and sells forest machines for the cut-to-length (CTL) method and related information systems enabling logistics control and measurements for the harvesting chain. An important business area is the maintenance services that are offered throughout the lifetime of the machine. Originally, the forest machines and information systems were developed for Scandinavian conditions but the portfolio has been developed to match the diverse needs and demands of forest machine entrepreneurs globally: nowadays different tree species, climate conditions and terrains are considered in the design. Almost every machine is manufactured on order and $70 \%$ of the components are made in-house.

In the following, we will first discuss the sphere of deductive strategy making of the HQ and describe the values leading the organization. Then, we will describe the tensions arising in different relationships of subsidiaries and constituting these relationships. We show the typology of the practices through which the subsidiaries manage these tensions and which produce the position as an outcome of these everyday coping activities involved.

\subsection{Sphere of deductive strategy making of the $\mathrm{HQ}$}

The MNC in question is a highly values-led organization. Instead of strict control practices, they have aimed to make certain core beliefs and assumptions explicit in interactions, 
highlighted also by posters on the walls of the headquarters. Respect for and understanding of the hard work their customers do is the foundation of the business. They maintain grassrootlevel touch and emphasize the importance of 'being in the same boat' with the customers. As the majority of their customers are individual foresters and small businesses, the MNC wishes to see itself in a similar way: as a family business without hierarchies or bureaucracy, although being a listed company. Values are the basis for maintaining a sense of purpose and relatedness of people, in particular emphasized since 2009:

"...the values, the way to operate. These are the things with which we roll, here's the direction and basis, and then we'll just live according to each economic situation."

In 2010, the MNC gave up the market area governance by the headquarters through vicepresident posts. Subsidiary managers and regional directors became the persons responsible for the local subsidiaries, having a direct contact with the local customers. The aim was to decentralize responsibility and decision-making, but at the same time, the management started pondering about different ways to measure the effectiveness of the emerging local management models. All the subsidiaries (except in the UK) are led by Finnish managers and form the extended family of the MNC: both employees and customers alike are cared for. What the headquarters expect from the subsidiaries is that they function as independent units, reflecting the same core values in the operations but thinking for themselves and making decisions at the spot. The MNC aims at maintaining the contact with the subsidiaries through regular meetings and board activities, but does not wish to meddle in with the everyday activities as long as sales quotas are reached.

Still, certain hierarchical tension exists between the HQ and the subsidiaries. It relates to the subsidiary's relative location between the parent and the local market. It is a question of the control exerted by the headquarters and the agency enacted by the subsidiary. All the 
subsidiaries have had the freedom to develop their operations quite independently, but being a listed company, the question of the "right" level of corporate governance is to be found.

"[Each] company is like the manager of it. In my opinion, in this size of the corporation, it shouldn't be true anymore. We have talked a lot in our management group about the processes and that we need to have certain ways of operations regardless of who is the managing director. Of course, the fingerprint of the managing director is seen in these companies, when they are small."

\subsection{Sphere of inductive strategy making of a subsidiary}

The subsidiary-level sphere and reality of strategy making is different than in the HQ due to the different local network the subsidiary is embedded in. The relationships and stakeholders the local firm has each pose their own demands for the local operations, and tensions arise between the differing interests of the actors. Through these tensions and the developed ways to deal with them, the organization is positioning itself in the network. Even though the subsidiaries are drawing on the same practices due to the guidance through values, they are producing and reproducing them in different ways, on demands of the local relationships.

Each location has their unique set of customers even though the industry and the methods used in tree-cutting are roughly the same. In Sweden, the customers are divided into three categories: individual entrepreneurs with one or two machines; medium-sized companies with 5-10 machines; and big companies with up to 100 machines. Even the smaller customers act closely with forest industry companies or saw mills; hence, the customer's customers are also an important part of the sales process. In the US, customers are mainly private, small customers. A typical customer is a family business with two machines, a harvester, and a forwarder. Moreover, in Russia, customers are a heterogeneous group varying from small contractors to 
multinational companies. No matter how many machines the customers have, the primary condition for the machinery sales is working after-sales: spare parts, maintenance and training. Performance requirement tension arises from the fact that while customers have to wait for the service or spare parts, the profitability of the machine decreases as they are losing money. As the core values of the MNC include quality and helping the customers whenever needed, respect of customer's work is an important guideline. On the other hand, resources for covering the whole market area are limited, and the subsidiaries have been forced to develop solutions that will help them to keep their promises. Swedish subsidiary has suffered from credibility issues due to the limited service resources compared with the wide market area, and they aim to strengthen their service network by establishing their own units.

"At the moment, the burden is that we are present in the whole Sweden. We have given a promise that we will cover the entire country. It is quite a long and wide country. ... It might be an internal thing that we have started to think about that perhaps in certain areas we are not credible in the service. If there are big machine entrepreneurs that have, let's say ten machines, and we have one person and a bus responsible for the service, this kind of bus entrepreneur, it is not a credible choice."

In the US service operates a lot through a helpdesk phone. A wider area can be covered since $80 \%$ of the problems can be solved on the phone, and it saves both the customers', and supplier's time. In Russia, the challenge is the same but has been solved by using full-line dealers that both sell and service machinery. The maintenance people also often travel from headquarters in Finland to Russia, as the maintenance service requires special expertise with new and all the time more developed machines. The same applies to training as well: complicated machines take time to learn how to make the most of them, and the more quickly the drivers learn, the more rapidly the investment starts to pay itself back to the customer. 
Image tension with respect to the way the customers see the manufacturer, is another feature related to the credibility: whether the manufacturer can be trusted or not. As a relatively small newcomer as a corporation compared with the American and Japanese industry leaders, the MNC has been labeled as a "small sweater army" by the competitors. The way wood is cut also follows long, often regional, traditions, but when the relationship is close, also change of mindsets becomes possible through practices, such as site visits:

"[Our machines] have been used in Europe already a half a decade now. [...] three years ago I started to talk to one of our clients [in the US] that you have to try these. He didn't believe in the system at all. Said that they won't work. I said that 'listen, try them'. We ordered the machines to them, and he tried, and after that, it started to fly. He saw how it could be done. We actually visited one working site in Europe with this customer and took a look at the machines."

The down-to-earth manners and dedication to deep customer understanding as the core of the corporate culture has led to gaining a good reputation and a steady market share rise. Owners' and top managers' partaking in customer events and sales negotiations have helped to create a trusting atmosphere within the customer relationships.

"It all comes from the fact that we really do these things differently, and customers are close. There are no hierarchies or layers between the customers and us, but anybody can walk in through the door and come to talk at any time."

Innovation tension is about the company's existing solutions and customers' developing needs. Each subsidiary answers this tension differently, partly according to their preferences and partly according to headquarters' guidelines, and according to the enabling and restricting factors of their other relationships. The local customer base provides a set of conditions and needs for harvesting. Sweden is said to be a major market for innovations since the Nordic countries have long traditions in harvesting. The Finnish and Swedish customers determine 
much of the development of new models, which is not always well fitting to other markets, such as Russia. Russian customers would have other ideas that are not always realized.

"But it [Russia] is a critical market area also regarding product development, and there is much innovative thinking and willingness to experiment. We get much product development ideas and ideas for improvement."

On the other hand, the US subsidiary provides an example of how innovation tension was solved in the US through personal relationships. The subsidiary started co-operation with the state of Arizona which had a problem with juniper thorugh personal contact by the mayor. The US subsidiary developed a special kind of head with which to cut juniper, and the state is now covering the expenses of the local machine demos by the subsidiary.

Innovation tension arises also from the relationships with the other subsidiaries. The subsidiaries compete against each other in several ways and in family spirit. The tension arises from the success factors identified in other subsidiaries and in attempts to try out and copy the best practices, applied to the local conditions.

"Everybody has built his or her own business, sales, and service in the environment and everyone has done it in his or her own way. It has not been guided in any other way than by saying that 'sell'. ... Now we are ... looking for those best practices and try to distribute them. They will take them and mold them to fit their culture. I don't think you can force them into a form; it does not work in that way. It's the end of everything, innovativeness and own activity."

Resource tension, on the other hand, arises e.g. when the subsidiary has to compete internally over the manufacturing capacity with the other subsidiaries. Especially after the launch of the new model the sales figures have risen drasticly, and customers have made many pre-orders. The problem is the backlog with delivery, and customers have to wait even six months to get their machines. Especially in Russia, this is too long time for many customers. 
"People do not wait around here; half a year is too long. [...] the name of the game is that when the buying or financing decision has been made, the machine is wanted immediately. Moreover, that thinking is not likely going to change. That has been quite well taken into consideration [within the firm]. We have a monthly quota of which we will get the machines. However, since the business is good also in other parts of the world, it has not always been possible to keep our share as well as we wanted to."

Agency tension arises in the internal network of the subsidiary, with both employees and partners. The tension results from the expectations the firm has towards them, and the internal volitions of the employees and partners. First, tension that requires attention relates to the way the employees see themselves as part of the firm and their rights and responsibilities when acting as the company representatives. The US and Russian subsidiaries have been happy with the commitment the personnel shows and the managers say they could not wish for a better team. Turnover in personnel is minimal and therefore also the personnel holds valuable knowhow that is impossible to teach to a newcomer in a short period of time. On the other hand, the difficulties the Swedish subsidiary has faced have had a lot to do with the atmosphere and commitment of the personnel. Different measures have been taken by the latest manager in order to improve the motivation of the employees and atmosphere of the subsidiary in general and progress has been made gradually.

“...I have said to the salespeople that 'when you make a sale, you write down in the contract everything that you have agreed with the customer but after that, you will not meddle with it in any way'. Moreover, we have gone through the process a lot, that things would not be promised orally since they are impossible [to control]. Especially in this case when this salesperson left, we have received phone calls that he promised this and that. How are you going to check that, there is no way? So we have tried to 
go through the process and learn all the things that might even feel like ridiculous or self-evident."

The agency tension is even more evident with the partners as they are not part of the organization as such and therefore it is harder to make sure that the quality is at the level that it should be. The local organizing needs to be done based on the partners available, and therefore the practices differ accordingly. Swedish subsidiary is handling the sales themselves and not utilizing dealers, but for service they are utilizing an external maintenance network because of the limited resources to build their own service network. The Russian subsidiary uses multiple dealers both in sales and service. They have eight dealers who are responsible for sales, service and training. In addition to that the Russian subsidiary has a few partners only focusing on service. The US subsidiary has five own full line units with sales, service, spare parts and training. Also, they have five service dealers that do not do sales, just service, and parts. The experience the customer gets from the company is highly dependent on the partners' activities, and therefore choosing the right partners is a primary goal.

"Q: What do you want to see in the dealer to whom you would allow also do sales?

A: I would like to see that it is our duplicate [laugh].

Q: What, are you looking for a certain way of doing things, corporate culture, or competence of certain kind?

A: I mean the way the company is ran, what kind of personnel, what kind of units and service cars, all these kinds of things. It is no use to give this sort of product to a company that is just going to ruin it."

Another feature describing internal network relationships is competence tension: what kind of competence the personnel holds and what is needed. Therefore, the company has put a lot of effort into training and staff development. This is also reflected in the grassroots 
orientation as a value in the corporation; people need to have hands-on knowledge of the machines and the customers, no matter at what level they work.

"Yeah we could not clone him, so we had to get somebody else. However, this other guy, he is also a long-term member of the family, have been working as the senior mechanic. He has a long experience of all kinds of problems that there is. He was the best guy for the job. ... You cannot take a guy like that from outside; there is nobody since you have to train those kinds of guys yourself."

Performance requirement tension and image tension with the customers is reflected also in the competitor relationships since it is the competitors to whom the company is being compared. Tensions exist even though the subsidiaries would not be that close with the competing firms' representatives as they follow their actions through different channels. The MNC has its way of doing business and the competitors have their own. With their unique approach and culture, it has been easy for the company to create an image of their own and differentiate themselves from the competitors. Even though it has managed to grow their market share in all three market areas, the competitors have not responded by trying to imitate their practices.

“We follow the competitors' marketing all the time, and of course their doings with the machines. $R \& D$ is following, we follow their patents. ... and follow the market share development."

Depending on both the competitors and the subsidiary in question, these tensions are managed through different kind of practices - although the focus points in the business are the same at each subsidiary. The values: quality, respect for customers, and grass-root orientation are visible in all subsidiaries in the form of including top management in customer events and activities and taking good care of service and training. 
"The competitors do not do this [training]. Those two competitors that are located here in the same village, they do not have any training. When a customer buys a machine, he's on his own; it's like learn yourself. Moreover, [a competitor] has one trainer for the whole upper parts of the states. There's no way he can train them all. That training, that's a huge thing."

"It's the flat organization that annoys them. Our CEOs, chairmen of the board take part in customer things and actually talk to people here. I believe that is the biggest thing, the biggest difference."

Table 2 collects the tensions we saw represented in the data as the determinants of the relationship practices and network positioning of the subsidiaries. We as well link the tensions with corporate values and give examples of the activity related with the practices and the underlying tensions.

Insert Table 2 about here.

\section{Discussion}

The results of the analysis reveal that a network position of a subsidiary (and, the whole MNC) is not something static or fixed, even though it might be considered as stable for lengthened periods of time. The relationship between strategy and positioning from a network view is intriguing. Even though 'position' and 'positioning' are concepts used in the 'positioning school' of strategic management (Porter, 1980; Mintzberg et al., 1997), network view of positioning is profoundly different because the networks and relationships are the basis of analysis, not an individual firm (see Baraldi et al., 2007). 
Here, the network position is seen in relational terms: it is not a 'thing' but a continuously changing nexus of tensions and those practices that have been born to deal with these tensions. Each subsidiary is a part of a different kind of network of relationships, and therefore, also the tensions take different forms. Depending on the local context and the features of the relationships as well as the way the subsidiary managers perceive these tensions and tries to find solutions for balancing them, the subsidiaries develop differently. The tensions are not bad or good things as such; they are a natural part of relationships, and due to these tensions the organizations change and develop.

We emphasize the subsidiaries' strategy-making in networks to emerge in interaction with the deductive, purposeful strategic activity of the headquarters and with the practices of adapting to and developing of the dynamic market networks. These strategic practices are driven by their underlying tensions, i.e. "elements that seem logical individually but inconsistent and even absurd when juxtaposed" (Smith \& Lewis, 2011, p. 328).

The dynamics defining the position of the subsidiaries are described through the shared values, practices, and identified tensions in Figure 2. The outer circle depicts the sphere of deductive strategy making: the corporate-level mechanism in which the positioning is part of deliberate strategizing and resource coordination activities conditioned by the multiple embeddedness of the subsidiaries. Our examination points to the MNC level corporate values as a strong medium against the hierarchical and resource tensions inevitably existing within the MNC internal network. Also the integration the headquarters aims to achieve comes through the explicitly expressed values and the purpose of the firm. These together form the underlying logic or 'modus operandi' of the MNC activities despite the differences of the subsidiaries and their local contexts and everyday practices.

In the "periphery", or the local markets, strategy comes through the strategic practices based on the corporate values, which are very similarly seen and adopted in all the subsidiaries, 
even though the actual activities take different forms depending on the local conditions. This inner circle describes the sphere of inductive strategy making in which the position emerges through the dynamics of relationship tensions and the strategic practices. The relationships of each subsidiary are different, and therefore the tensions have different manifestations. As a result, each subsidiary chooses their way of reacting to these tensions. Subsidiary managers have a central role in molding the practices through which subsidiaries aim at balancing these tensions. It is the combination of the practices that produces the position in the everyday activities of the subsidiaries.

Insert Figure 2 about here.

\section{Conclusions}

The aim of our study was to understand how the positioning of a subsidiary develops through strategic practices in the changing MNC networks. Our findings hold two key notions. First, we build on the existing literature on strategy in business networks (e.g., Jüttner \& Schlange, 1996; Holmen \& Pedersen, 2003; Baraldi et al., 2007; Harrison \& Prenkert, 2009; Hulthén \& Torvatn, 2014; Cheng \& Holmen, 2015; Mota et al., 2016; Szalkai \& Magyar, 2017) and show how positioning of a subsidiary in its local markets is more than a question of internal organizational design (Bartlett \& Ghoshal, 1989) or of handling the external relationships (Andersson et al., 2002). Instead it is a question of strategic practices, i.e. the logics of acting and interacting and routinized patterns of actions at the interactive spheres between individuals in the connected companies (Chia \& MacKay, 2007; see also Baraldi et al., 2007). Hence, we draw on and elaborate the notion of network position (Johanson \& Mattsson, 1988) by viewing the position as constantly evolving and embedded (see Schepis et al., 2014). It is not 
planned or managed by any individual actor, but relates with the conscious activity of people in influencing the network parties.

Second, we highlight the strategic complexity of network embedded organizations by bringing into the light the different tensions resulting from the relationship dynamics that manifest themselves at the level of human doings of the MNC managers (cf. Baraldi et al., 2007). The tensions of competence, agency, image, innovation and performance requirements all are closely interrelated with the personalities, responsibilities and trustworthiness at the individual level. Even the solving of the hierarchical and resource tensions takes different forms on the basis of the individuals' ways of managing at the different interaction spheres. As a result, we present the mechanism of subsidiary positioning. The mechanism shows the interaction of both deductive and inductive strategy making in which these two intertwined cycles of strategy-making are based on the values-led control of the headquarters and the relationship dynamics in the local markets.

Previous research on networks (e.g. Håkansson \& Snehota, 1989; Möller \& Svahn, 2003; Ritter, Wilkinson \& Johnston, 2004) has paid limited attention to strategic management in network context although firms in networks are seen to take strategic actions to influence their positioning in their surrounding network (Johanson \& Mattsson, 1992). This study contributes to the IMP view of strategy (Baraldi et al., 2007; Jüttner \& Schlange, 1996) by defining the mechanism of practice-based subsidiary positioning at internal and external interaction spheres of the MNC and showing how the tensions and the strategic practices shape the positioning.

Furthermore, we contribute to network approach by elaborating on the view of network positioning in MNCs as happening in two overlapping interaction spheres, where subsidiaries are simultaneously embedded in the internal MNC networks and the local market networks. Through the dynamic view of tensions at the intersection of the internal and external networks, this research also contributes to understanding of change and transformation of business 
networks. It emphasises the dual nature of change as both deliberate and emergent (see Håkansson \& Snehota, 1995; Mintzberg et al., 1998) and shows the continuity of change in a business network.

Our findings highlight three main learning points relevant to managers working in MNCs and seeking better ways to understand subsidiary positioning. First, our research identifies a number of corporate values and links them to underlying tensions and gives examples of related practices and activities. These corporate values can guide the operations of the whole MNC by providing a tool for the headquarters to achieve integration necessarily needed in MNCs. Values can also be used as a medium in lowering the hierarchical and resource tensions. Supported by the values the managers can lead the MNC towards a shared goal and form a more unified and consistent picture of the supplier in relation to its customers.

Second, the results of this study suggest a critical link between subsidiary positioning to its local markets and relationship practices, showing how the subsidiary positioning is about constantly acting and interacting and forming routinized patterns of actions. For managers it is important to keep in mind that the position in local markets cannot be managed by one person or actor. Instead the position is constantly evolving, and therefore one is to accept change as the prevailing state. Thirdly, by modeling the practice-based network positioning of MNC subsidiaries as a dynamic play of tensions, our study provides an illustration about the subsidiaries' development and their positioning in their networks. As network positioning is one of the central activities of strategic decision making in the MNCs, understanding the special characteristics of subsidiaries can help managers to understand how strategy becomes through practices as an interplay between shared global and unique local requirements.

One may argue that our methodological approach has some limitations. We have chosen to focus on only one company. Our data consists of two interview rounds as well as archival data, meetings and videos. The interviewees recollect past events and therefore it could be that 
their interpretations would be different if we would have interviewed them at other times. On the other hand, in this research it is not relevant whether the views of managers reflect the actual course of events, instead pivotal is that these views guide their actions. In addition, we have not done interviews with the external partners, customers or competitors of the MNC, which could have shed more light on the business network as a whole and therefore opens an avenue for future research.

\section{References}

Adenfelt, M., \& Lagerström, K. (2006). Knowledge development and sharing in multinational corporations: The case of a centre of excellence and a transnational team. International Business Review 15(4), 381-400.

Andersson, U., Forsgren, M. \& Holm, U. (2002). The strategic impact of external networks: subsidiary performance and competence development in the multinational corporation. Strategic Management Journal 23(11), 979-996.

Axelsson, B. \& Easton, G. (Eds.). (1992). Industrial Networks: A New View of Reality. London: Routledge.

Baraldi, E., Brennan, R., Harrison, D., Tunisini, A., \& Zolkiewski, J. (2007). Strategic thinking and the IMP approach: A comparative analysis. Industrial Marketing Management 36(7), 879-894.

Bartlett, C.A. \& Ghoshal, S. (1989). Managing Across Borders: The Transnational Solution.

Boston, MA: Harvard Business School Press.

Bartlett, C.A. \& Ghoshal, S. (2002). Managing Across Borders: The Transnational Solution. Harvard Business Press.

Birkinshaw, J. \& Hood, N. (1998). Multinational subsidiary evolution: capability and charter change in foreign-owned subsidiary companies. Academy of Management Review 23(4), 
773-795.

Bouquet, C., \& Birkinshaw, J. (2011). How global strategies emerge: an attention perspective. Global Strategy Journal 1(3- 4), 243-262.

Cheng, C., \& Havenvid, M. I. (2017). Investigating strategy tools from an interactive perspective. IMP Journal 11(1), 127-149.

Cheng, C. \& Holmen, E. (2015). Relationship and networking strategy tools: characterizing the IMP toolbox. IMP Journal 9(2), 177-207.

Chia, R. (1994). The concept of decision: a deconstructive analysis. Journal of Management Studies 31(6), 781-806.

Chia, R. and Holt, R. (2006). Strategy as practical coping: A Heideggerian Perspective. Organization Studies 27(5), 635-655.

Chia, R., \& MacKay, B. (2007). Post-processual challenges for the emerging strategy-as practice perspective: Discovering strategy in the logic of practice. Human Relations 60(1), 217-242.

Creswell, J. W. (2013). Qualitative Inquiry and Research Design: Choosing Among Five Approaches. LA: Sage.

Denzin, N.K. \& Lincoln, Y.S. (2000). Handbook of Qualitative Research. CA: Thousand Oaks, 633-643.

Easton, G. (1992). Industrial networks: A review. In Axelsson B. \& Easton, G. (Eds.), Industrial Networks: A New View to Reality. London: Routledge.

Easton, G. (2010). Critical realism in case study research. Industrial Marketing Management 39(1), 118-128.

Flick, U. (2004). Design and process in qualitative research. In Flick, U., von Kardoff, E. \& Steinke, I. (Eds.), Qualitative Research. London: Sage Publications, 146-152.

Forsgren, M. (2008). Theories of The Multinational Firm: A Multidimensional Creature in The 
Global Economy. Cheltenham, UK: Edward Elgar.

Gadde, L. E., Huemer, L., \& Håkansson, H. (2003). Strategizing in industrial networks. Industrial Marketing Management 32(5), 357-364.

Ghauri, P. (2004). Designing and conducting case studies in international business research. In: Marschan-Piekkari, R. \& Welch, C. (Eds.), Handbook of Qualitative Research Methods for International Business. Cheltenham: Edward Elgar, 109-124.

Ghoshal, S., Korine, H. \& Szulanski, G. (1994). Interunit communication in multinational corporations. Management Science 40(1), 96-110.

Gupta, A. K., \& Govindarajan, V. (2000). Knowledge flows within multinational corporations. Strategic Management Journal 21(4), 473-496.

Halinen, A., \& Törnroos, J. A. (2005). Using case methods in the study of contemporary business networks. Journal of Business Research 58(9), 1285-1297.

Halinen, A. \& Mainela, T. (2013). Challenges of longitudinal field research in process studies on business networks. In: Raukko, M. \& Paavilainen-Mäntymäki, E. (Eds.): Handbook of Longitudinal Research Methods in Studies of Organizations. Edward Elgar Publishing.

Harrison, D., \& Prenkert, F. (2009). Network strategising trajectories within a planned strategy process. Industrial Marketing Management 38(6), 662-670.

Harrison, D., Holmen, E., \& Pedersen, A. C. (2010). How companies strategise deliberately in networks using strategic initiatives. Industrial Marketing Management 39(6), 947955.

Hedlund, G. (1986). The hypermodern MNC - A heterarchy? Human Resource Management $25(1), 9-35$.

Heidegger, M. (1971). Building dwelling thinking. In: Poetry, Language, Thought (trans. by Albert Hofstadter). New York: HarperCollins, 141-159.

Henneberg, S. C., Naudé, P. \& Mouzas, S. (2010). Sense-making and management in business 
networks: Some observations, considerations, and a research agenda. Industrial Marketing Management 39(3), 355-360.

Holmen, E., \& Pedersen, A. C. (2003). Strategizing through analyzing and influencing the network horizon. Industrial Marketing Management 32(5), 409-418.

Håkansson, H., \& Snehota, I. (1989). No business is an island: the network concept of business strategy. Scandinavian Journal of Management 4(3), 187-200.

Håkansson, H. \& Snehota, I. (1995). Developing Relationships in Business Networks. London: Routledge.

Håkansson, H., \& Ford, D. (2002). How should companies interact in business networks? Journal of Business Research 55(2), 133-139.

Hulthén, K., \& Torvatn, T. (2014). Footprints of Strategy: Investigating Purchasing Strategies in a Longitudinal Case. The IMP Journal 8(3), 120-132.

Jarzabkowski, P. (2004). Strategy as practice: recursiveness, adaptation, and practices-in-use. Organization Studies 25(4), 529-560.

Jarzabkowski, P. (2005). Strategy as practice: An activity based approach. London: Sage.

Jarzabkowski, P., Kaplan, S., Seidl, D., \& Whittington, R. (2016). On the risk of studying practices in isolation: Linking what, who, and how in strategy research. Strategic Organization 14(3), 248-259.

Jarzabkowski, P. \& Paul Spee, A. (2009). Strategy- as- practice: A review and future directions for the field. International Journal of Management Reviews 11(1), 69-95.

Johanson, J. \& Mattsson, L-G. (1988). Internationalisation in industrial systems - A network approach. In: Ford, D. (1997) (2nd ed.) Understanding Business Markets: Interaction, Relationships and Networks. London: Dryden Press, 194-213.

Johanson, J. \& Mattsson, L. G. (1987). Interorganizational relations in industrial systems: A network approach compared with the transaction-cost approach. International Studies of 
Management \& Organization, 34-48.

Johanson, J. \& L.-G. Mattsson (1992). Network positions and strategic action - an analytic framework. In: Axelsson, B. \& Easton, G. (Eds.). Industrial Networks: A New View of Reality. London: Routledge.

Johanson, J. \& Vahlne, J. E. (2009). The Uppsala internationalization process model revisited: From liability of foreignness to liability of outsidership. Journal of International Business Studies 40(9), 1411-1431.

Jüttner, U., \& Schlange, L. E. (1996). A network approach to strategy. International Journal of Research in Marketing 13(5), 479-494.

Ljung, A. \& Pahlberg, C. (2015). Subsidiary strategy processes in Latin America. European Business Review 27(5): 535-550.

MacKay, R. B., \& Chia, R. (2013). Choice, chance, and unintended consequences in strategic change: a process understanding of the rise and fall of Northco Automotive. Academy of Management Journal 56(1), 208-230.

Mattsson, L. G. (1987). Management of strategic change in a 'markets-as-networks' perspective. The Management of Strategic Change, 234-256

Medlin, C. J., \& Törnroos, J. Å. (2014). Interest, sensemaking and adaptive processes in emerging business networks-An Australian biofuel case. Industrial Marketing Management 43(6), 1096-1107.

Melin, L. (1989). The field-of-force metaphor. Advances in International Marketing 3, 161179.

Meyer, K. E., Mudambi, R., \& Narula, R. (2011). Multinational enterprises and local contexts: The opportunities and challenges of multiple embeddedness. Journal of Management Studies 48(2), 235-252.

Mintzberg, H., Ahlstrand, B., \& Lampel, J. (1998). Strategy Safari. NY: The FreePress. 
Mota, J., de Castro, L. M. \& Brito, C. (2016). “Powered by... whom?” A network perspective on replication as strategy. Journal of Business Research 69(11), 4732-4736.

Munksgaard, K. B., \& Medlin, C. J. (2014). Self-and collective-interests: Using formal network activities for developing firms' business. Industrial Marketing Management 43(4), 613621.

Möller, K., \& Svahn, S. (2003). Managing strategic nets a capability perspective. Marketing Theory 3(2), 209-234.

Nell, P. C., Ambos, B. \& Schlegelmilch, B. B. (2011). The MNC as an externally embedded organization: An investigation of embeddedness overlap in local subsidiary networks. Journal of World Business 46(4), 497-505.

Pedersen, T., Devinney, T. M., Venzin, M., \& Tihanyi, L. (2014). Orchestration of the Global Network Organization (Vol. 27). Bingley, UK: Emerald.

Piekkari, R., Plakoyiannaki, E. \& Welch, C. (2010). 'Good' case research in industrial marketing: Insights from research practice. Industrial Marketing Management 39(1), 109-117.

Powell, W. W., \& Smith-Doerr, L. (1994). Networks and economic life. The Handbook of Economic Sociology 368, 380.

Piekkari, R., \& Welch, C. (2010). The human dimension in multinational management: A way forward. Scandinavian Journal of Management 26(4), 467-476.

Pernu, E., Mainela, T., \& Puhakka, V. (2014). Organizing MNC internal networks to manage global customers: Strategies of political compromising. Advances in International Management 27, 349-376.

Porter, M. E. (1980). Competitive Strategy: Techniques for Analyzing Industries and Competitors. New York: The Free Press.

Regnér, P. (2003). Strategy creation in the periphery: Inductive versus deductive strategy 
making. Journal of Management Studies 40(1), 57-82.

Ritter, T., Wilkinson, I. F. \& Johnston, W. J. (2004). Managing in complex business networks. Industrial Marketing Management 33(3), 175-183.

Ryan, A., Tähtinen, J., Vanharanta, M., \& Mainela, T. (2012). Putting critical realism to work in the study of business relationship processes. Industrial Marketing Management 41(2), $300-311$.

Schatzki, T. (2001). Introduction: Practice Theory. In: Knorr-Cetina, K., von Savigny, E., \& Schatzki, T. R. (Eds.). The Practice Turn in Contemporary Theory. Routledge, 1-14.

Schepis, D., Purchase, S., \& Ellis, N. (2014). Network position and identity: A languagebased perspective on strategizing. Industrial Marketing Management 43(4): 582.

Silverman, D. (2005). Doing Qualitative Research: A Practical Handbook. London: Sage.

Smith W. K \& Lewis M.W. (2011). Toward a theory of paradox: A dynamic equilibrium model of organizing. Academy of Management Review 36(2), 381-403.

Szalkai, Z. \& Magyar, M. (2017). Strategy from the perspective of contract manufacturers. IMP Journal 11(1), 150-172

Thorelli, H. B. (1986). Networks: between markets and hierarchies. Strategic Management Journal 7(1), 37-51.

Tsoukas, H. (1989). The validity of idiographic research explanations. Academy of Management Review 14(4), 551-561.

Vahlne, J., Schweizer, R., \& Johanson, J. (2012). Overcoming the liability of OutsidershipThe challenge of HQ of the global firm. Journal of International Management 18(3), 224232.

Whittington, R. (1996). Strategy as practice. Long Range Planning 29(5), 731-735. 
TABLE 1

Empirical data of the case study.

\begin{tabular}{|c|c|c|}
\hline \multicolumn{3}{|l|}{ Interviews } \\
\hline Interviewee & Date & Duration Concentration \\
\hline Chairman of the board & Feb 2014 & 1h $45 \mathrm{~min}$ History of the firm, internationalization \\
\hline $\mathrm{CEO}$ of the firm & Feb 2014 & 1h $12 \mathrm{~min}$ Present challenges of the firm \\
\hline Chairman of the board & Apr 2014 & Internal organizing, key individuals \\
\hline Managing director, Sweden AB & Apr 2014 & Development of the Swedish subsidiary \\
\hline Managing director, USA Inc. & Apr 2014 & Development of the American subsidiary \\
\hline Managing director, Russia OOO & Apr 2014 & 1h $11 \mathrm{~min}$ Development of the Russian subsidiary \\
\hline $\begin{array}{l}\text { CEO of the firm and the } \\
\text { Chairman of the board }\end{array}$ & Jan 2016 & $\begin{array}{l}\text { Development of the firm and the three } \\
\text { subsidiaries 2014-16 }\end{array}$ \\
\hline g director, Sweden AB & Mar 2016 & Development of the subsidiary 2014-16 \\
\hline g director, USA Inc. & Mar 2016 & 1h 16 min Development of the subsidiary 2014-16 \\
\hline Managing director, Russia $\mathrm{OOO}$ & Apr 2016 & 1h $12 \mathrm{~min}$ Development of the subsidiary 2014-16 \\
\hline \multicolumn{3}{|l|}{ Archival data } \\
\hline Type of data & Period & Role in research process \\
\hline Annual reports & $2000-2015$ & $\begin{array}{l}\text { Understanding of historical development, strategic } \\
\text { choices and organizational structure and culture }\end{array}$ \\
\hline Company history & Until 2000 & Understanding major developments 1970-2000 \\
\hline Press releases & $2002-2015$ & $\begin{array}{l}\text { Increased understanding of the important events in } \\
\text { the development of MNC and its subsidiaries }\end{array}$ \\
\hline Web pages of the company & 2014-2015 & $\begin{array}{l}\text { Basic information about the company, products, } \\
\text { operation logic and organization }\end{array}$ \\
\hline Brochures/presentation material & 2014 & Views to the organizational culture and values \\
\hline Industry analyses & $2005-2009$ & The key developments in the industry \\
\hline \multicolumn{3}{|l|}{ Videos and meetings } \\
\hline Type of data & Timing & Role in research process \\
\hline Factory visit with the CEO & Feb 2014 & \multirow{2}{*}{$\begin{array}{l}\text { Discussion with the CEO, deeper understanding of } \\
\text { the production process and operations of the factory } \\
\text { Getting acquainted with subsidiaries, understanding } \\
\text { the organization culture and atmosphere }\end{array}$} \\
\hline Yearly subsidiary meeting & Apr 2014 & \\
\hline Anniversary celebration in & Mar, May & \multirow[t]{2}{*}{$\begin{array}{l}\text { Understanding of organizational culture and the } \\
\text { Swedish market }\end{array}$} \\
\hline & & \\
\hline Product launch in the US videos & Jun 2014 & $\begin{array}{l}\text { Understanding of organizational culture and the } \\
\text { American market }\end{array}$ \\
\hline $\begin{array}{l}\text { Model series launch and logging } \\
\text { in Russia videos }\end{array}$ & $\begin{array}{l}\text { Dec } 2014, \\
\text { Apr } 2015\end{array}$ & $\begin{array}{l}\text { Understanding of organizational culture and the } \\
\text { Russian market }\end{array}$ \\
\hline
\end{tabular}


TABLE 2

\section{Tensions and related strategic practices.}

\begin{tabular}{|c|c|c|c|}
\hline Tension & Practice & Underlying values & Example of activity \\
\hline Resource tension & Resource planning & $\begin{array}{l}\text { Trustworthiness: } \\
\text { Keeping promises }\end{array}$ & $\begin{array}{l}\text { Using quotas, } \\
\text { diminishing the backlog }\end{array}$ \\
\hline $\begin{array}{l}\text { Innovation tension } \\
\text { (subsidiary network) }\end{array}$ & Sharing experiences & $\begin{array}{l}\text { Valuing and } \\
\text { developing } \\
\text { competence of } \\
\text { individuals }\end{array}$ & $\begin{array}{l}\text { Sharing and copying best } \\
\text { practices }\end{array}$ \\
\hline $\begin{array}{l}\text { Innovation tension } \\
\text { (customers) }\end{array}$ & Problem-solving & $\begin{array}{l}\text { Respect for } \\
\text { customers, Care- } \\
\text { taking }\end{array}$ & $\begin{array}{l}\text { Responding to customer } \\
\text { requests }\end{array}$ \\
\hline Hierarchical tension & Grassroot orientation & $\begin{array}{l}\text { Family values, } \\
\text { equality }\end{array}$ & $\begin{array}{l}\text { Top management visiting } \\
\text { customer events }\end{array}$ \\
\hline $\begin{array}{l}\text { Agency tension } \\
\text { (employees, partners) }\end{array}$ & Family-like atmosphere & $\begin{array}{l}\text { Family values, care- } \\
\text { taking }\end{array}$ & $\begin{array}{l}\text { Dividing responsibility; } \\
\text { requiring results } \\
\text { Providing support and } \\
\text { training }\end{array}$ \\
\hline $\begin{array}{l}\text { Competence tension } \\
\text { (employees, partners) }\end{array}$ & $\begin{array}{l}\text { Personal development and } \\
\text { training }\end{array}$ & $\begin{array}{l}\text { Valuing and } \\
\text { developing } \\
\text { competence of } \\
\text { individuals, } \\
\text { Trustworthiness }\end{array}$ & $\begin{array}{l}\text { Organizing training for } \\
\text { employees and partners }\end{array}$ \\
\hline $\begin{array}{l}\text { Performance requirement } \\
\text { tension (customers, also } \\
\text { competitors) }\end{array}$ & Quality priority & $\begin{array}{l}\text { Quality priority: } \\
\text { "Right at the first } \\
\text { time" } \\
\text { Respect for customers }\end{array}$ & $\begin{array}{l}\text { Excellent service and } \\
\text { spare part coverage }\end{array}$ \\
\hline $\begin{array}{l}\text { Image tension } \\
\text { (customers, also } \\
\text { competitors) }\end{array}$ & $\begin{array}{l}\text { Trustworthiness; } \\
\text { approachability }\end{array}$ & $\begin{array}{l}\text { Family values, } \\
\text { Trustworthiness, } \\
\text { Respect for } \\
\text { customers: } \\
\text { appreciation of their } \\
\text { work, } \\
\text { Grassroot orientation }\end{array}$ & $\begin{array}{l}\text { Taking care of customers; } \\
\text { down-to-earth marketing } \\
\text { campaigns }\end{array}$ \\
\hline
\end{tabular}


FIGURE 1

Practice based MNC strategy-making in business networks.

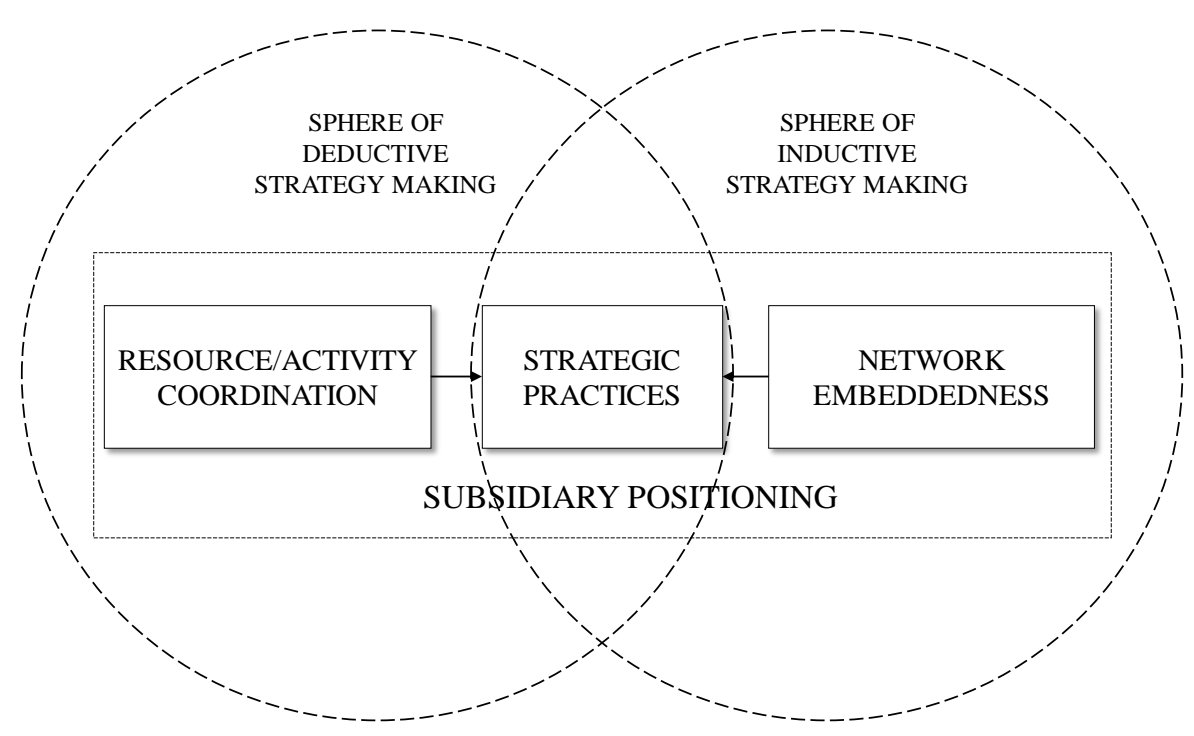


FIGURE 2

The mechanism of the practice-based positioning of MNC subsidiaries.

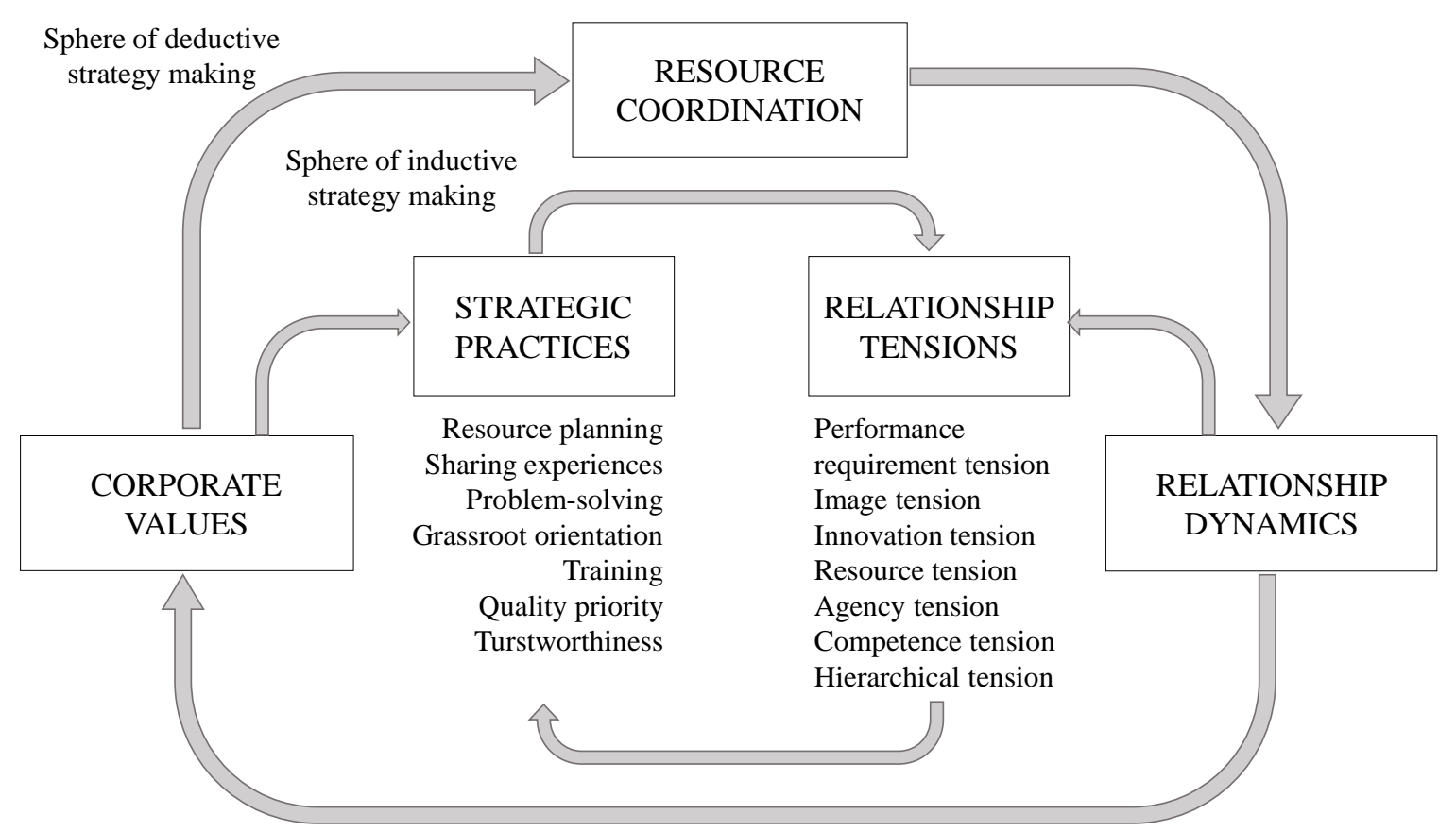

